\title{
LYSOSOMAL ENZYME RELEASE FROM LUTEINIZED RAT OVARIES BY PROSTAGLANDIN $\mathrm{F}_{2 \alpha}$
}

\author{
R. WEINER AND G. KALEY \\ Department of Physiology, New York Medical College, \\ Valhalla, New York 10595, U.S.A.
}

(Received 24th Fanuary 1975)

Extensive evidence has been amassed which demonstrates that prostaglandin (PG) $F_{2 \alpha}$ plays an important role in the regulation of CL function. Recently, several experimental findings have buttressed the hypothesis that $\mathrm{PGF}_{2 \alpha}$ is the uterine luteolytic factor. It has been reported that $\mathrm{PGF}_{2 \alpha}$ induces degeneration of the CL of the pseudopregnant rat (Pharriss \& Wyngarden, 1969), and other mammals (Duncan \& Pharriss, 1970; Kirton et al., 1970; McCracken et al., 1970 ), that it decreases ovarian progesterone secretion in pregnant and pseudopregnant rats (Behrman et al., $1971 \mathrm{~b}$ ), and that it is identifiable in uterine venous blood of guinea-pigs and sheep toward the end of the oestrous cycle, a time which coincides with luteal regression (Bland et al., 1971; Blatchley et al., 1972). Although these aforementioned data clearly demonstrate the luteolytic properties of $\mathrm{PGF}_{2 \alpha}$, the cellular mechanism(s) by which $\mathrm{PGF}_{2 \alpha}$ acts are poorly understood. In view of the findings that $\mathrm{PGF}_{2 \alpha}$ labilizes lysosomes of rat liver (Weiner \& Kaley, 1972), pancreas, spleen and kidney cortex (Ignarro et al., 1973), and that increased lysosomal enzyme activity occurs in rat lutein cells undergoing involution (Lobel et al., 1961), the present study was undertaken to determine the effects of $\mathrm{PGF}_{2 \alpha}$ on acid hydrolase release from lysosomes of luteinized ovaries.

In order to obtain large amounts of relatively uniform luteal tissue, the superovulation procedure of Parlow (1958) was utilized. Immature female Holtzman rats 25 to 27 days old were treated with 50 i.u. PMSG followed 60 hr later with 25 i.u. HCG. The excessively luteinized ovaries were collected 7 days after ovulation, pooled, minced in vessels kept on cracked ice and homogenized in ice-cold $0.25 \mathrm{M}$-sucrose buffered to $\mathrm{pH} 7.4$ with $0.01 \mathrm{M}$-tris using a motor-driven Teflon pestle and glass mortar. All subsequent preparative procedures were carried out at 0 to $4^{\circ} \mathrm{C}$. A modification of the method of Dingle (1961) was employed to harvest lysosomes from the resultant homogenates. Ovarian homogenates were centrifuged at $800 \mathrm{~g}$ for $10 \mathrm{~min}$ to remove nuclei and unbroken cells. The supernatant was then centrifuged at $10,000 \mathrm{~g}$ for $20 \mathrm{~min}$ to sediment the large granule fraction containing lysosomes. This crude lysosomal pellet, which also contained microsomes, was resuspended in buffered sucrose and its protein concentration determined by the method of Lowry et al. (1951), employing bovine albumin as a standard. The suspension was then resedimented by centrifugation at $10,000 \mathrm{~g}$ for $20 \mathrm{~min}$. 
A pair of rat ovaries was taken to provide each $2.0 \mathrm{ml}$ aliquot of lysosomeenriched suspension containing $1 \mathrm{mg}$ granule protein $/ \mathrm{ml}$ buffered sucrose. These lysosomal suspensions were incubated with $\mathrm{PGF}_{2 \alpha}$ or a solution (control) in which the PG was dissolved (trimethylol aminomethane, THAM, $6 \cdot 8 \mu \mathrm{g} / \mathrm{ml}$ ). Incubations were carried out for $30,60,90$ and 120 min at $37^{\circ} \mathrm{C}$ with gentle shaking. After the incubation, suspensions were cooled on ice, centrifuged at $20,000 \mathrm{~g}$ for $20 \mathrm{~min}$, and the activity of $\beta$-glucuronidase released into the supernatant was determined. Total $\beta$-glucuronidase activity was measured in the $20,000 \mathrm{~g}$ supernatant of an aliquot of lysosomal suspension which had been exposed to mechanical disruption in a Virtis homogenizer for $3 \mathrm{~min}$ and to thermal shock by five alternate freeze-thaw cycles.

The activity of $\beta$-glucuronidase (EC 3.2.1.31) was determined at $\mathrm{pH} 4.5$ in acetate buffer utilizing phenolphthalein glucuronide as the substrate according to the procedure of Fishman et al. (1948). Released acid hydrolase, an index of lysosomal fragility, was calculated in units of $\mu \mathrm{g}$ phenolphthalein liberated $/ \mathrm{mg}$ granule protein $/ \mathrm{hr}$ at $37^{\circ} \mathrm{C}$, and also expressed as the $\%$ of total $\beta$-glucuronidase activity.

Table 1. Effect of $\mathrm{PGF}_{2 \alpha}(20 \mu \mathrm{g} / \mathrm{ml})$ on $\beta$-glucuronidase release from lysosomal suspensions of luteinized rat ovaries

\begin{tabular}{|c|c|c|c|c|}
\hline $\begin{array}{l}\text { No. of } \\
\text { experiments }\end{array}$ & $\begin{array}{c}\text { Time of } \\
\text { incubation } \\
\text { at } 37^{\circ} \mathrm{C}(\text { min })\end{array}$ & $\begin{array}{l}\% \text { Total } \\
\beta \text {-glucuronidase } \\
\text { released }\end{array}$ & $\begin{array}{l}\text { Difference } \\
\text { from control }\end{array}$ & $\begin{array}{l}\% \text { Change } \\
\text { from control* }\end{array}$ \\
\hline 15 & 30 & $20.07 \pm 0.82 \dagger$ & $\begin{array}{l}+1 \cdot 17 \pm 0.23 \\
(2 P<0.001 \ddagger)\end{array}$ & $\begin{array}{l}+6.2 \pm 1.2 \\
(2 P<0.001)\end{array}$ \\
\hline 15 & 60 & $23.09 \pm 0.99 \dagger$ & $\begin{array}{l}+1 \cdot 18 \pm 0.49 \\
(2 P<0.05)\end{array}$ & $\begin{array}{c}+5.6 \pm 2 \cdot 1 \\
(2 P<0.02)\end{array}$ \\
\hline 15 & 90 & $26 \cdot 39 \pm 1 \cdot 17 \dagger$ & $\begin{array}{l}+0.97 \pm 0.33 \\
(2 P<0.01)\end{array}$ & $\begin{array}{c}+3 \cdot 7 \pm 1.2 \\
(2 P<0.005)\end{array}$ \\
\hline 15 & 120 & $32 \cdot 50 \pm 1.56 \dagger$ & $\begin{array}{l}+1.99 \pm 0.40 \\
(2 P<0.001)\end{array}$ & $\begin{array}{c}+6.7 \pm 1.2 \\
(2 P<0 \cdot 001)\end{array}$ \\
\hline
\end{tabular}

All values are means \pm S.E.M.

* Control release of $\beta$-glucuronidase assigned a value of 100 .

$\dagger$ Release of $\beta$-glucuronidase significantly greater in each successive time period, $2 P<0.02, t$ test.

$\ddagger P$ values were calculated by paired $t$ test.

Supernatants of the lysosomal suspensions from the luteinized ovaries incubated for $30 \mathrm{~min}$ with buffered sucrose containing THAM (controls, $\mathrm{n}=15$ ) had $45.02 \pm 3.21$ (mean \pm S.E.M.) $\beta$-glucuronidase units, which corresponded to $18.90 \pm 0.77 \%$ of the total $\beta$-glucuronidase activity. The effects of $\mathrm{PGF}_{2 \alpha}$ on lysosomal fragility are depicted in Table 1. Lysosomal suspensions incubated with $20 \mu \mathrm{g} \mathrm{PGF}_{2 \alpha} / \mathrm{ml}$, showed a significantly increased release of lysosome-bound $\beta$-glucuronidase with time, and liberated significantly more enzyme than control suspensions at each incubation time studied. That the $\mathrm{PGF}_{2 \alpha}$-induced increase in enzyme activity is due to a direct action on lysosomes is supported by the fact that $\mathrm{PGF}_{2 \alpha}$ had no demonstrable effect on $\beta$-glucuronidase activity when it was added to particle-free supernatants containing the enzyme (seven paired experiments). 
Increased activity of lysosomal enzymes is an early event associated with luteal regression, and undoubtedly plays a pivotal role in the involution of the CL of the rat (Lobel et al., 1961) and the ewe (Deane et al., 1966). It has, moreover, been shown by Dingle et al. (1968) that lysosomes obtained from sheep CL undergoing regression exhibit a significantly greater fragility, as measured by the release in vitro of lysosomal marker enzymes in response to a standard physical stress, than those obtained from animals in early oestrus, or pregnancy. In the light of these experiments it was suggested that the uterine luteolytic factor affects lysosomes directly and that the resultant increase in enzyme leakage is perhaps the primary cause of regressive changes in the CL.

The ability of $\mathrm{PGF}_{2 \alpha}$ to initiate luteolysis when administered in vivo (Pharriss \& Wyngarden, 1969) and its inability to do so when incubated with ovarian tissue in vitro (Sellner \& Wickersham, 1970) led to the proposal of a possible vascular mechanism for $\mathrm{PGF}_{2 \alpha}$ action which was thought to be mediated by vasoconstriction of the uterine and utero-ovarian veins (Pharriss et al., 1970). It would appear, however, that $\mathrm{PGF}_{2 a}$ does not produce a sufficient reduction in blood flow to the CL to substantiate this mechanism (Bruce \& Hillier, 1974). Furthermore, it has recently been demonstrated that $\mathrm{PGF}_{2 \alpha}$ markedly inhibits progesterone synthesis by rabbit CL in vitro (O'Grady et al., 1972). These reports suggest a direct effect by $\mathrm{PGF}_{2 \alpha}$ on luteal tissue. The studies of Behrman et al. (1971 a) imply that $\mathrm{PGF}_{2 \alpha}$ may produce a 'biochemical' lesion in the lutein cell which results in the lack of adequate storage of cholesterol esters and the consequent impaired ability of the cell to synthesize progesterone. The results of our studies, showing that PGF $_{2 \alpha}$ labilizes lysosomes of luteinized rat ovaries, bridge the gap between the previously obtained biochemical and morphological findings and the putative physiological role of $\mathrm{PGF}_{2 \alpha}$ as the uterine luteolytic factor, and may provide an insight into the mechanism by which PGF $_{2 \alpha}$ produces luteolysis in vivo.

This study was supported by a grant from the National Heart and Lung Institute, USPHS. Thanks are due to Dr J. Jewel for HCG, Dr J. Pike for prostaglandin $F_{2 \alpha}$, Dr A. F. Parlow for PMSG and Mr Asefa Gebrewold for his technical assistance.

\section{REFERENCES}

Behrman, H.R., MacDonald, G.J. \& Greep, R.O. (1971a) Regulation of ovarian cholesterol esters: evidence for the enzymatic sites of prostaglandin-induced loss of corpus luteum function. Lipids 6 , 791-796.

Behrman, H.R., Yoshinga, K. \& Greep, R.O. (1971b) Extraluteal effects of prostaglandins. Ann. N.Y. Acad. Sci. 180, 426-435.

Bland, K.P., Horton, E.W. \& Poyser, N.L. (1971) Levels of prostaglandin F $_{2 \alpha}$ in the uterine venous blood of sheep during the oestrous cycle. Life Sci. 10, 509-517.

Blatchley, F.R., Donovan, B.T., Horton, E.W. \& Poyser, N.L. (1972) The release of prostaglandins and progestin into the utero-ovarian venous blood of guinea pigs during the oestrous cycle and following oestrogen treatment. F. Physiol., Lond. 223, 69-88.

Bruce, N.W. \& Hillier, K. (1974) The effect of prostaglandin $F_{2 \alpha}$ on ovarian blood flow and corpora lutea regression in the rabbit. Nature, Lond. 249, 176-177.

Deane, H.W., Hay, M.F., Moor, R.M., Rowson, L.E.A. \& Short, R.V. (1966) The corpus luteum of the sheep: relationships between morphology and function during the oestrous cycle. Acta endocr., Copenh. 51, 245-263. 
Dingle, J.T. (1961) Studies on the mode of action of excess vitamin A. 3. Release of a bound protease by the action of vitamin A. Biochem. 7. 79, 509-512.

Dingle, J.T., HAY, M.F. \& Moor, R.M. (1968) Lysosomal function in the corpus luteum of the sheep. 7. Endocr. 40, 325-336.

Duncan, G.W. \& Pharriss, B.B. (1970) Effect of nonsteroidal compounds on fertility. Fedn Proc. Fedn Am. Socs exp. Biol. 29, $1232-1239$.

Fishman, W.H., Springer, B. \& Brunetti, R. (1948) Application of an improved glucuronidase assay method to the study of human blood $\beta$-glucuronidase. 7 . biol. Chem. 173, 449-456.

Ignarro, F.J., Oronsky, A.L. \& Perper, R.J. (1973) Effects of prostaglandins on release of enzymes from lysosomes of pancreas, spleen and kidney cortex. Life Sci. 12, 193-201.

Kirton, K.T., Pharriss, B.B. \& Forbes, A.D. (1970) Luteolytic effects of prostaglandin $F_{2 \alpha}$ in primates. Proc. Soc. exp. Biol. Med. 133, 314-316.

Lobel, B.L., Rosenbaum, R.M. \& Deane, H.W. (1961) Enzymic correlates of physiological regression of follicles and corpora lutea in ovaries of normal rats. Endocrinology 68, 232-247.

Lowry, O.H., Rosebrough, N.J., FARR, A.L. \& Randall, R.J. (1951) Protein measurement with the Folin phenol reagent. 7 . biol. Chem. 193, 265-275.

MaCracken, J.A., Glew, M.E. \& Scaramuzzi, R.J. (1970) Corpus luteum regression induced by prostaglandin $\mathrm{F}_{2 \alpha}$. F. clin. Endocr. Metab. 30, 544-546.

O'Grady, J.P., Kohorn, E.I., Glass, R.H., Caldwell, B.V., Brock, W.A. \& Speroff, L. (1972) Inhibition of progesterone synthesis in vitro by prostaglandin $\mathrm{F}_{2 \alpha}$. F. Reprod. Fert. 30, 153-156.

Parlow, A.F. (1958) A rapid bioassay method for $\mathrm{LH}$ and factors stimulating LH secretion. Fedn Proc. Fedn Am. Socs exp. Biol. 17, 402.

Pharriss, B.B. \& Wyngarden, L.J. (1969) The effect of prostaglandin $F_{2 \alpha}$ on the progestogen content of ovaries from pseudopregnant rats. Proc. Soc. exp. Biol. Med. 130, 92-94.

Pharriss, B.B., Cornette, J.C. \& GutKnecht, G.D. (1970) Vascular control of luteal steroidogenesis. 7. Reprod. Fert., Suppl. 10, 97-103.

Sellner, R.G. \& Wickersham, E.W. (1970) Effects of prostaglandins on steroidogenesis. F. Anim. Sci. 31, 230.

WeINER, R. \& KALEY, G. (1972) Lysosomal fragility induced by prostaglandin F $_{2 \alpha}$. Nature, New Biol. $236,46-47$. 